\title{
Mind the gap between high school and university! A field qualitative survey at the National University of Caaguazú (Paraguay)
}

This article was published in the following Dove Press journal:

Advances in Medical Education and Practice

25 May 2016

Number of times this article has been viewed

\author{
Anna Siri ${ }^{1,2}$ \\ Nicola Luigi Bragazzi ${ }^{1-3}$ \\ Hicham Khabbache ${ }^{4}$ \\ María Maddalena \\ Spandonari ${ }^{5}$ \\ Luis Alberto Cáceres ${ }^{5}$ \\ 'Department of Mathematics (DIMA), \\ University of Genoa, Genoa, Italy; \\ 2UNESCO CHAIR "Anthropology \\ of Health - Biosphere and Healing \\ System", University of Genoa, Genoa, \\ Italy; ${ }^{3}$ Department of Health Sciences \\ (DISSAL), University of Genoa, \\ Genoa, Italy; ${ }^{4}$ Faculty of Literature \\ and Humanistic Studies, Sais, Sidi \\ Mohamed Ben Abdellah University, \\ $\mathrm{Fez}$, Morocco; ${ }^{5} \mathrm{Administrative}$ \\ Direction, Universidad Nacional de \\ Caaguazú, Coronel Oviedo, Paraguay
}

Correspondence: Nicola Luigi Bragazzi School of Public Health, Department of Health Sciences (DISSAL), University of Genoa, Via Antonio Pastore I, Genoa 16132, Italy

Email robertobragazzi@gmail.com

\begin{abstract}
Paraguay has eight public universities and 45 private universities. The National University of Caaguazú (Universidad Nacional de Caaguazú or UNCA), with its main campus located in Coronel Oviedo, is one of the most recently founded public universities, being established in 2007. The UNCA has launched a project aiming at exploring the potentiality of its educational system, as well as its gaps. In particular, the UNCA wants to assess the effectiveness of preparatory courses for preparing students for admission to the degree course in medicine (Cursos Probatorios de Ingreso or CPI), in order to identify the main strong and weak points of the system, the popularity and usefulness of CPI as perceived by the students, the students' and teachers' opinions regarding the limits of school, and their suggestions. This paper is based on a field survey and highlights the care that must be taken in order to develop conditions respectful of the wellbeing of those participating in the educational context.
\end{abstract}

Keywords: university students, school-university transition, social inclusion, drop-out, preparatory courses

\section{Introduction}

The current economic situation is challenging the higher education system, which should be able to reconcile two opposing imperatives: namely, the need to contain its budget and the need to preserve and maintain high quality standards. On the other hand, investing in human capital is crucial for fostering any recovery in economy. ${ }^{1,2}$

Traditionally, total public spending on education in Latin America is lower than the Organisation for Economic Co-operation and Development (OECD) countries, even though these differences have recently begun to reduce. An average of $4 \%$ of the gross domestic product is spent on education, representing a slight increase since 2000, while the average for the OECD is approximately 5\%. Distribution by levels shows that education expenditure is concentrated on primary and secondary education; while the level of spending on pre-school education, despite low coverage, is close to that of OECD countries. ${ }^{3}$ The recent increase in public spending per student (for both primary and secondary education) is linked to improvements in the education conditions. Between 1990 and 2000, school coverage was increased, even though this limited the average spending per student. Between 2000 and 2008, the increase in spending was used to improve conditions that affect the quality of education, such as infrastructure, equipment and didactic materials, among others. However, spending on tertiary education remains below the OECD average, with some important exceptions 
(namely, Colombia, Uruguay, and the Bolivarian Republic of Venezuela). ${ }^{3}$

Regarding public investment per student, spending on tertiary education is higher than the expenditure for other education levels. On the other hand, for a notable group of countries, this indicator has decreased, in particular for Argentina, Chile, Paraguay, and Colombia. ${ }^{3}$

\section{The problem of university drop-out}

Rates of drop-out and regularity of studies represent two important indicators of efficacy, both in terms of outcomes and process, of teaching performance.

In particular, drop-out is a complex, multi-factorial phenomenon, determined by a multiplicity of often interrelated causes that negatively affect performance, leading to non-attendance. Drop-out imposes a heavy economic burden to the society, in terms of resources used, costs incurred, and the amount of individual and collective investments in human capital that turn out to be an unproductive loss.

Analyzing the processes that could lead to drop-out may be a step toward a better clarification of the phenomenon and, consequently, may underpin strategies effective to its reduction.

As such, many research projects started in particular in the United Kingdom, United States, Australia, but also, more recently, in Latin American countries. ${ }^{4-6}$

The vast literature on drop-out is largely theoretically dominated by the student integration model, developed by Tinto $^{7-9}$ in which the complex interaction between the individual characteristics in terms of parental, social, educational background, and the educational environment offered by a specific university plays a major role. Further extensions of this model are given by Astin's Theory of Involvement, ${ }^{10}$ Bean's Student Attrition Model, and its subsequent version, modified by Bean. ${ }^{11}$

However, these models have been specifically designed for the American context, ${ }^{12-18}$ and are difficult to practically apply in a reality situation such as Latin America, where the quality of education is particularly low and ensuring education coverage and completion is a challenging issue. Given the relevance of the drop-out problem in all Latin American countries, in September 2005 the International Seminar "Rezago deserción y en la educación superior" took place at the University of Talca (Chile). The final report showed that the factors influencing drop-out can be grouped into: economic factors; family factors; academic factors; and subjective factors, such as reasons for choosing the course, the perceived image of a given professional role, and personal or family members' health problems.

Often, these causes can overlap. The academic and structural factors, all of them originating from the so-called internal selectivity and the impact of the university, require a capacity for autonomy and competence that the student may not possess. Moreover, the student also has to face the socalled external selectivity, which is the result of the action of external social contexts at cognitive (motivation, professional image, etc), relational (social reference subjects such as family), and material (economic conditions, housing, etc) levels.

In order to improve retention rates and reduce drop-outs and transfers, intensive interventions are required as early as possible, not only to identify students at risk, but also to prepare students for higher educational experiences. ${ }^{19,20}$

In the Latin American context, the phenomenon of drop-out has a certain relevance, reaching 57.5\%. ${ }^{21}$ However, despite the importance of this topic, there is a dearth of studies. For example, in Paraguay, where only $5.3 \%$ of people aged 25 years old or more have completed tertiary education, ${ }^{21}$ there are few publications. ${ }^{22-24}$

\section{The transition from high school to university}

When analyzing the causes that may lead to drop-out, the transition from high school to university plays a major role. ${ }^{25-27}$ It represents, indeed, a distinct, particularly critical period in a student's educational career, as it places the student in front of several changes, including, in particular, the organization of studying activities and the way of approaching them. The transfer involves adolescents in transition toward adulthood and struggling to learn a new studying system that requires more flexibility, self-regulation, and self-organization.

Some authors ${ }^{28}$ have shown that in the phase of entrance into the new university environment the student may be more vulnerable and exposed to critical experiences. The transfer determines, indeed, a change from the state of dependent to independent learner, from studying in a carefully monitored environment with a highly regulated timetable to a new phase of life where learners manage their time and make decisions in a more responsible adult way.

In several studies a variety of pre-university projects and partnerships designed to facilitate entry and transition, promoted by higher education institutions, have been mentioned and discussed. ${ }^{27,29-31}$ Some programs focus specifically on information, dissemination, and learning opportunities, while others are designed to prepare students for the schooluniversity transition. 
The current study concerns a pre-university project started at the National University of Caaguazú (Universidad Nacional de Caaguazú or UNCA), Paraguay.

\section{Material and methods}

According to the world ranking of the United Nations Program for Development, which includes 182 countries, Paraguay occupies position 101 on the Human Development Index, with a score of 0.761 (the average index of all Latin America and Caribbean countries being 0.821), and a literacy rate of $94.6 \%$ (position 94 on the world list). As for the number of students registered at all levels, Paraguay has approximately $11 \%-18 \%$ points less than the other Mercosur countries, occupying the $97^{\text {th }}$ position on the world list. In fact, only $72 \%$ of the school aged population of Paraguay participates in the educational system, in contrast to Uruguay and Argentina where $90 \%$ is reached.

Paraguay has eight public universities and 45 private universities. The UNCA with its main campus located in Coronel Oviedo, is one of the most recently founded public universities, being established in 2007. The UNCA has launched a project aiming at exploring the potentiality of its educational system, as well as its gaps. In particular, the UNCA wants to assess the effectiveness of preparatory courses in preparing students for admission to the degree course in medicine, in order to identify: strong and weak points of the system; popularity and usefulness of the "Cursos Probatorios de Ingreso" (CPI) as perceived by the students; students' and teachers' opinions with regard to the qualification of secondary school; and suggestions that could be useful to make any possible improvements.

The current study is a field qualitative survey, started at the beginning of the 2009 academic year through ad hoc questionnaires designed for students in preparatory courses or first year medicine, CPI lecturers, and secondary school teachers. They consisted of: one questionnaire aimed at all students enrolled in CPI course; one questionnaire aimed at all students enrolled in the first year of any university course; one questionnaire aimed at all CPI lecturers; one questionnaire aimed at high school teachers (convenience sample).

The specific objectives of the questionnaires were: to identify the main difficulties of transitioning from high school to university; to identify students' possible special needs in order to create a comprehensive educational system able to offer specific answers and prevent critical situations; to check possible secondary school teachers' interests in participating in a university specialization aimed at offering them not only continuous updates, but also contacts, sharing of methodologies and interdisciplinary approaches in order to realize a more careful and effective scholastic education; and to collect suggestions on improving the organization's preparatory courses and the students' qualification, as well as identifying new tools or adapting those already existing to real local situations in order to prevent university drop-out.

The data were collected, entered into a database, and processed with the commercial software for statistical analysis, MedCalc Statistical Software version 16.2.0 (MedCalc Software bvba, Ostend, Belgium; https://www.medcalc.org; 2016).

Written informed consent was obtained from the participants, after informing them of the aims of the research. The protocol of the study was reviewed and approved by the Ethical Committee of the UNCA, Paraguay.

\section{Results \\ Participants}

The participants who volunteered to take part in the study were: 113 students enrolled in medicine CPI; 14 students enrolled in first year of degree course in medicine; $17 \mathrm{sec}-$ ondary school teachers; and 15 CPI lecturers.

\section{Profile of the UNCA}

Students interested in enrolling in degree courses offered by the UNCA are increasing, as indicated in Table 1.

The commitment required for each course is approximately 850 hours (reduced to 550 in 2010); normal didactic activity takes place in the morning. The CPI is organized like a school: attendance is compulsory, with periodic and final assessments. Registration consists of paying a fee that covers all expenses relative to teaching and administration costs.

Students' interest in CPI has almost doubled in just 2 years. Table 2 summarizes entries in the first year of courses set up at the university that started their activities in 2008 launching the first "Cursos Probatorios de Ingreso" for medicine.

Many students, transferring from the first to the second year of college, did not register or did not attend lessons and did not sit exams.

The percentage, for each course of study, of students defined as "silent" (ie, students at risk of drop-out) is shown in Table 3.

\section{Information on university-high school counselling and guidance}

Sixty-five percent of students declared the information obtained at the moment of selecting the faculty as sufficient 
Table I Participants at preparatory courses for the admission test relative to years 2008-2010

\begin{tabular}{|c|c|c|c|c|c|c|}
\hline \multirow[t]{2}{*}{ Faculty } & \multicolumn{2}{|l|}{ Year 2008} & \multicolumn{2}{|l|}{ Year 2009} & \multicolumn{2}{|l|}{ Year 2010} \\
\hline & Number of CPI & $\begin{array}{l}\text { Number of } \\
\text { CPI students }\end{array}$ & Number of CPI & $\begin{array}{l}\text { Number of } \\
\text { CPI students }\end{array}$ & Number of CPI & $\begin{array}{l}\text { Number of } \\
\text { CPI students }\end{array}$ \\
\hline Medicine & 1 & 90 & 1 & 144 & 2 & $169 *$ \\
\hline Dentistry & - & - & I & 65 & I & $* *$ \\
\hline Nursing and midwifery & I & 44 & 2 & 44 & I & $* *$ \\
\hline Social and political sciences & I & 43 & 2 & 125 & I & $* *$ \\
\hline Science of production & I & 123 & I & 53 & I & $* *$ \\
\hline Science of economics & 1 & 226 & 2 & 235 & 2 & $45^{*}$ \\
\hline Science and technology & - & - & - & - & I & 187 \\
\hline
\end{tabular}

Notes: *This number is still partial as it represents those enrolled in the first CPI that was organized. At the time of draft of this work the number of students enrolled in the next CPI was unknown. ${ }^{* *}$ Number not yet available. The CPI started in November 20I0. Modified from authors' elaboration from university dataset. 23,24

Abbreviation: $\mathrm{CPI}$, preparatory courses for university admission.

Table 2 Students registered (years 2009 and 2010)

\begin{tabular}{|c|c|c|c|c|}
\hline \multirow[t]{2}{*}{ Faculty } & \multicolumn{2}{|c|}{$\begin{array}{l}\text { Students } \\
\text { registered } \\
\text { year } 2009\end{array}$} & \multicolumn{2}{|c|}{$\begin{array}{l}\text { Students } \\
\text { registered } \\
\text { year } 2010\end{array}$} \\
\hline & $\begin{array}{l}\text { First } \\
\text { year }\end{array}$ & $\begin{array}{l}\text { Second } \\
\text { year }\end{array}$ & $\begin{array}{l}\text { First } \\
\text { year }\end{array}$ & $\begin{array}{l}\text { Second } \\
\text { year }\end{array}$ \\
\hline Medicine & 40 & - & 40 & 29 \\
\hline Social and political science & 43 & - & 86 & 26 \\
\hline Science of production & 115 & - & 50 & 93 \\
\hline Economic science & 180 & - & 173 & 145 \\
\hline Science and technology & - & - & 136 & - \\
\hline Dentistry & - & - & 50 & - \\
\hline Nursing and obstetrics & 46 & - & 47 & 36 \\
\hline
\end{tabular}

Note: Modified from authors' elaboration from university dataset. ${ }^{23,24}$

Table 3 Students at risk of drop-out

\begin{tabular}{lllll}
\hline Faculty & $\begin{array}{l}\text { Students } \\
\text { registered } \\
\text { year I 2009 }\end{array}$ & $\begin{array}{l}\text { Students } \\
\text { registered } \\
\text { year II 20 I0 }\end{array}$ & $\begin{array}{l}\text { Silent } \\
\text { students* }\end{array}$ & $\begin{array}{l}\text { \% } \\
\text { "silent } \\
\text { students"* }\end{array}$ \\
\hline $\begin{array}{l}\text { Medicine } \\
\text { Social and }\end{array}$ & 40 & 29 & II & $28 \%$ \\
$\begin{array}{l}\text { political science } \\
\begin{array}{l}\text { Science of } \\
\text { production }\end{array}\end{array}$ & 115 & 26 & 17 & $40 \%$ \\
$\begin{array}{l}\text { Economic } \\
\text { science }\end{array}$ & 180 & 93 & 22 & $19 \%$ \\
$\begin{array}{l}\text { Nursing and } \\
\text { obstetrics }\end{array}$ & 46 & 36 & 35 & $19 \%$ \\
\hline
\end{tabular}

Notes: *'Silent student" means a student who is not active, has not registered for the following year or does not attend lessons, does not sit examinations, and will presumably leave the course. Modified from authors' elaboration from university dataset. ${ }^{23,24}$

and indicated that the primary source was the opinion of other students who had chosen the same career or were still registered or had already graduated (35\%). The brochures drawn up by the faculty $(27 \%)$ and the guidance provided by the administrative office (19\%) also played an important role in transmitting the necessary information to students. It is noteworthy that few students (4\%) obtained information on their future career from college delegates for counselling and guidance.

Students' preference when leaving high school was to obtain information from their peers or from other students. This fact represents a sign that a guidance policy that involves university students in subsequent years (eg, tutoring) can be a good way to enable an academic institution to provide the information necessary for a reasoned choice of future career.

\section{Information on students enrolled in the CPI of medicine}

As far as sex is concerned, most students are female (69\%). The students' average age is 19 years, with a minimum of 17 and a maximum of 24 years.

Sixty-five percent of students registered at the CPI declared that they were full-time students, while $34 \%$ had odd jobs, and the remaining $1 \%$ were in steady employment. Reading is considered one of their spare time activities by $96 \% ; 25 \%$ reported reading three books per month, $35 \%$ two, $33 \%$ one book, and the remaining $4 \%$ none ( $4 \%$ gave no answer).

When asked about their parents' educational level, students answered as shown in Figure 1.

\section{Information about school background}

Fifty-one percent of students graduated from grade 4, while $42 \%$ graduated from grade 5 .

With regard to the school career, $61 \%$ said they had been "top student" (in Spanish, mejor egresado) and 29\% said they had participated in Mathematics Olympiad.

Forty-nine percent of students said they had studied every day during college, while $9 \%$ said they only studied before exams, and $9 \%$ said they studied only a little. The remaining $33 \%$ did not answer. Sixty-eight percent felt their college 


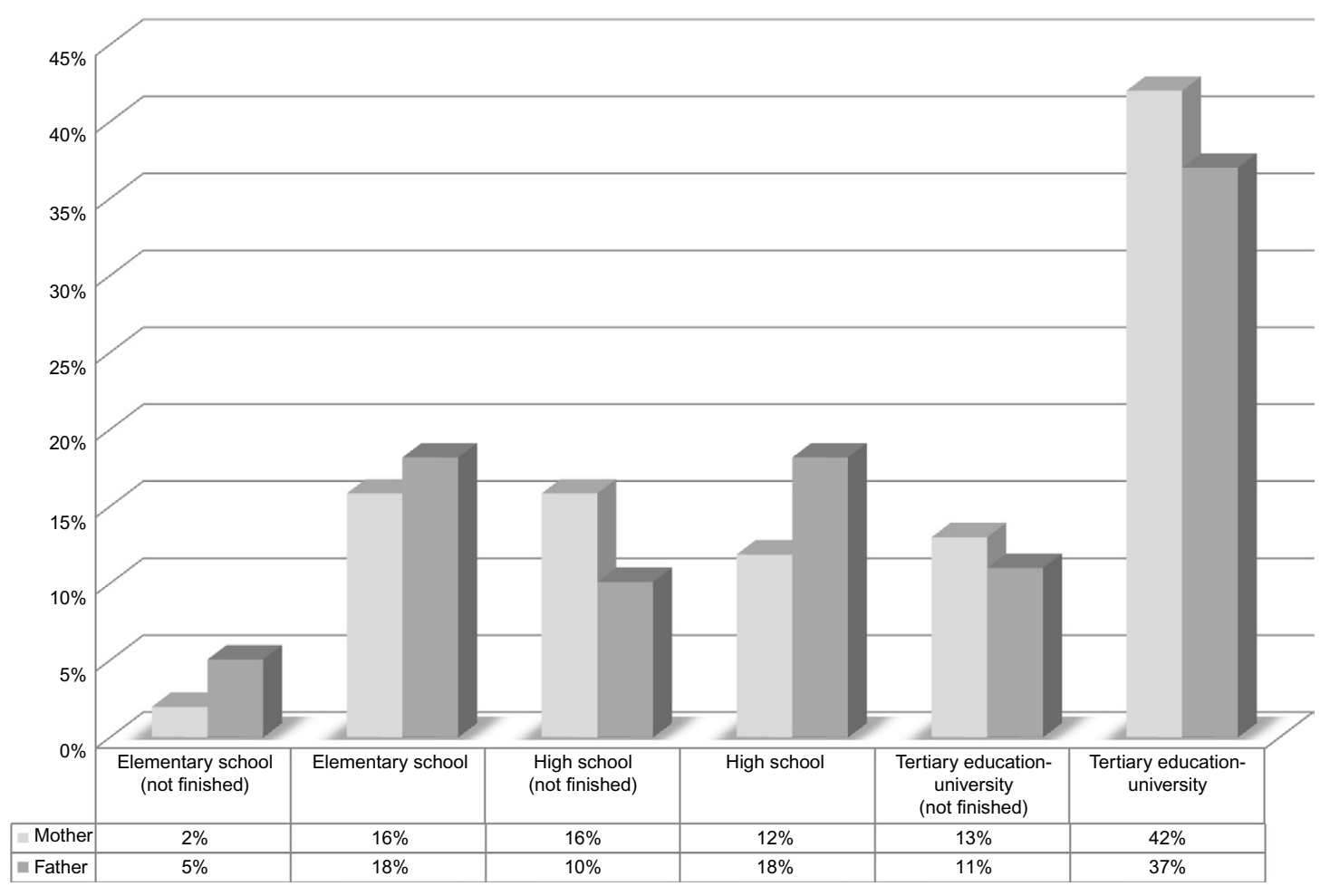

Figure I Parents' educational level.

Notes: Modified from authors' elaboration from university dataset. ${ }^{23,24}$

companions had an image of them as good students, while $26 \%$ felt they were considered excellent students.

At the end of college, based on their performance, $78 \%$ felt optimistic about their future at a university, 19\% believed they had the possibility of succeeding but were not sure, and noone reported to have felt pessimistic.

\section{Information about the CPI experience}

Seventy-three percent indicated that they did not register previously for any other CPI, 26\% said they had attended another CPI, $1 \%$ did not answer.

The frequency of study during the CPI has increased with respect to the commitment declared for high school. In fact, $86 \%$ said they studied daily for the CPI, while for high school the percentage was $49 \%$. Nine percent said they studied weekly when in the CPI and only $4 \%$ wrote that they only studied in periods close to exams ( $2 \%$ did not respond).

At the end of the CPI, based on the results obtained, $64 \%$ indicated that they had performed well, 23\% excellent, $10 \%$ sufficient, the remaining 3\% insufficient.

Optimism concerning their own qualification before entering the university did not change between the end of high school and the end of the CPI (78\%).

Fifty-six percent felt that they were perceived to be very good students, $38 \%$ good students, while $5 \%$ felt they were considered excellent students, 4\% acceptable, and 2\% not good at all.

Eighty-three percent said that they had encountered difficulties in transferring from high schools to universities because of an inadequate basic qualification (32\%), demanding university schedules and activities (25\%), and difficulty in adapting to the style of learning (24\%).

The organization of CPI timetable caused problems for $24 \%$ of students and the main reasons were incompatibility with work schedules and commuting difficulties.

\section{Students' personal reflections about high school}

Twelve percent of students said that globally they had received an excellent qualification, $42 \%$ said that it was good while $15 \%$ considered it sufficient, and $17 \%$ insufficient. Half the students felt that the basic qualification was generally adequate, even though lacking in areas such as physics (42\%), chemistry (34\%), and biology (19\%).

Seventy-eight percent of students considered a modification of high school didactics necessary, and $58 \%$ said that they had well qualified teachers. Eighty-six percent said they suffered from difficulties encountered in transferring from high schools to universities, particularly as a consequence of their previous basic qualification or timetables' organization. 


\section{Secondary school teachers' opinion concerning the transition phenomenon}

Forty-one percent of teachers teach mathematics and physics, $24 \%$ biology and chemistry, $17 \%$ Castilian and Guaraní, $12 \%$ history and philosophy, and $6 \%$ electronics. On the basis of the experience gained in high school, $71 \%$ of the professors believe that problems relating to transition from high school to university are substantial or even very relevant.

The subjects considered as most problematic are mathematics and physics, followed by Castilian, chemistry and biology, whilst Guaraní is not perceived as a difficult topic. In Table 4, on the basis of the order indicated, the index of difficulty was calculated, so as to identify subjects considered more difficult by secondary school teachers with respect to the transition to university.

Answering the question regarding how the high school prepares its students for a higher education, $76 \%$ replied "in a good way", the remaining $24 \%$ replied "in a sufficient way".

These data correspond to the perception of students regarding efficient secondary school qualification: approximately $50 \%$ of students had in fact answered that they had received a good/excellent qualification, and about $30 \%$ answered sufficient/insufficient.

Ninety-four percent of teachers think that solutions can be found to correct or improve the qualification of pupils who intend to pursue their studies, while all teachers believe that the task should be conjunctly carried out by schools and universities.

In particular, they perceived the following problems: inadequate basic qualification, an evaluation system too permissive and therefore not very selective, the curricular organization of the didactic activities which sees core subjects sacrificed, such as Castilian, mathematics, physics, chemistry and biology, in favor of other subjects inserted into the school programs during the last decade (eg, geology, logics, statistics, anatomy).

Table 4 Possible subjects considered difficult by students

\begin{tabular}{|c|c|c|c|c|c|c|}
\hline \multirow[t]{2}{*}{ Subjects } & \multirow{2}{*}{$\begin{array}{l}\text { Number of teachers } \\
\text { who reported the } \\
\text { subject }\end{array}$} & \multicolumn{4}{|c|}{$\begin{array}{l}\text { Order of } \\
\text { difficulty indicator }\end{array}$} & \multirow[t]{2}{*}{$\begin{array}{l}\text { Difficulty } \\
\text { index* }\end{array}$} \\
\hline & & 1 & 2 & 3 & 4 & \\
\hline Mathematics & 17 & 9 & 3 & 3 & 2 & 77.9 \\
\hline Physics & 12 & 4 & 5 & I & 2 & 51.5 \\
\hline Castilian & II & 2 & 6 & 1 & 2 & 44.1 \\
\hline Chemistry & 10 & 0 & 3 & 5 & 2 & 30.9 \\
\hline Biology & 4 & 2 & 0 & 2 & 0 & 17.6 \\
\hline Guaraní & $\mathrm{I}$ & 0 & 0 & 0 & I & 1.5 \\
\hline
\end{tabular}

Notes: *Values obtained on the scale of $\mathrm{I}-4$ were then re-proportioned in order to have a maximum score of 100 . Modified from authors' elaboration from university dataset. ${ }^{23,24}$
The existence of difficulties for some students related to text understanding and interpretation and teaching materials has also been highlighted.

The main difficulty for students in transferring from high school to universities are related to: a lack of autonomy and/ or self-adjustment to new studying methods; and a poor command of jargon. These issues become even more important in classes consisting of students of different ethnic, linguistic or social groups.

Moreover, current trends in the organization of university courses foresee courses of shorter duration and more focused on time, with a greater number of lessons compared to the past, packaged programs, and a greater dispersion of the students' efforts. It is therefore necessary to organize activities that promote reflection on the representations chosen and the aims of the activities performed.

The teachers have expressed much interest in opening a special university-high school program to favor an adaptation of functional programs to continuity of education. Similarly they declared their interest for training courses organized by area, managed by universities, and directed at retraining secondary school teachers; as well as for university training initiatives aimed at standardizing teaching methods and providing theoretical and practical basics to test new teaching tools and methodologies. However, many of them stated that such initiatives should be agreed upon between the Ministry of Education and the university.

Some of the most significant suggestions expressed by teachers were the following: changing the evaluation system, which is considered too permissive; changing management strategies and preservation of lecture halls; study and application of new teaching methods able to engage and motivate students; and reform of secondary school curricula, in a way to obtain uniformity with educational needs and standards required by universities.

\section{Opinion of CPI teachers regarding the transition phenomenon}

The hours available in the CPI are not perceived to be sufficient to carry out the entire program, particularly in light of the heterogeneity of knowledge of enrolling students, while it has been confirmed that some subjects taught in secondary schools after the reform have been "stealing space" from subjects deemed more important for the qualification of students intending to pursue further studies.

All the teachers deemed any coordinated action, taken by the university, aimed at creating a connection (or network) 
between secondary school and university educational activities, highly useful.

\section{Discussion}

A training system that contemplates preparatory courses before entering university, organized and managed by the faculty, is extremely interesting and meets the needs identified in several countries around the world with an insufficient scholastic qualification. This system allows the administration to have an active role in the transition process from high school to university that is not limited to the design phase, but foresees continuous and vigilant monitoring during all phases of the process.

This system would ensure a high quality educational process. Further, serving vulnerable subjects, it would not create social inequalities. In fact, if students were required to turn to private institutions in order to become qualified for university, this would create differences arising from the socio-economic family conditions. Moreover, during the CPI, the faculties have the opportunity to guide students; they can also identify, on the basis of motivation and talent, those who might better succeed in the chosen university course, and eventually direct toward other courses.

Our study underlines a basic structural academic problem: namely, the poor link between high school and university. The insufficient basic qualification could be resolved by strengthening the cooperation between high schools and universities in building courses able to allow students a continuum between different educational experiences.

The difficulty of adapting to a given teaching style is closely related to the study method. Some students develop a personal method during high school and in many cases they will be able to successfully adapt their method to a new environment. But it is not uncommon to arrive at university and realize that what worked well in the past is not producing the expected results anymore. In this case it is necessary to try to find new tools.

In fact, guidance does not only mean illustrating the educative offer to high school students, but is positively useful to avoid the risk of drop-out, at least in the sense that the student usually enrolls in a university course because he is influenced by the novelty, driven by vague interest, with no awareness of the skills necessary to successfully cope with the new learning. This same information provides guidance by stressing the importance of reflecting on the activities implemented during the delicate period of transitioning from high school to university.

\section{Conclusion}

There is a dearth of studies on the Paraguayan educational system. Our field qualitative survey, concerning the problems associated with the transitioning from high schools to universities, is aimed at beginning to fill in this gap.

Our study emphasizes the importance of evaluating educational processes in terms of satisfaction, learning, individual professional growth, organizational impact as well as improvement of the efficiency of services provided to the final users. Evaluation should become an integral and not episodic part of educational processes, in order to provide an effective contribution to improvements during the year and at the moment of defining subsequent plans.

With regard to the issue of school to university transition, the need to create effective liaisons and coordination between schools and universities emerges with more and more intensity, as though it was a bridge in which all educational actors like institutions, families, students, stakeholders, working world and, above all, political authorities may be involved.

On the one hand, school and university systems must train young people in order for them to achieve a fast and functional integration into the working world; on the other hand, the possibility of fitting into that world is deeply dependent on specialization and professionalism.

In fact, the qualification is the necessary instrument for acquiring a strategic capability to live and adapt to the changing working and professional world.

Schools and universities must therefore examine strategies to promote the design of integrated courses encouraging early orientation programs, specifically designed to capture mismatches between objectives/experiences and expectations concerning young people's future.

All this becomes indispensable also in view of a definition of training courses on those subjects identified as key stages in the transition period between school and university, in order to allow effective and functional teaching of those disciplines that the university values as indispensable.

Another element that emerged from our study is the strong interest among secondary school teachers to retrain themselves both on innovative educational models able to stimulate individuals in training and enhance their skills, and on attitudes and methodologies able to create an immersive and engaging learning setting that increases the students' degree of motivation and interest toward a given subject.

Further surveys as well as longitudinal studies undertaken by the UNCA are needed to monitor the evolution of students' motivations, expectations, and difficulties encountered as well as the effectiveness of adopted practices and interventions.

\section{Disclosure}

The authors have no conflict of interest to disclose. 


\section{References}

1. OECD. Education at a Glance 2013. OECD; 2013. Available from: http:// OECD indicator http://www.oecd.org/edu/eag2013\%20\%28eng\%29-FINAL\%2020\%20June\%202013.pdf. Accessed May 6, 2016.

2. United Nations Development Programme. Human Development Report 2013. UNDP; 2013. Available from: http://www.undp.org/content/dam/ undp/library/corporate/HDR/2013GlobalHDR/English/HDR2013\%20 Report\%20English.pdf. Accessed May 6, 2016.

3. OECD (Organisation for Economic Co-operation and Development), 2010. Latin American Economic Outlook 2011, OECD, Paris. Available from: http://www.latameconomy.org/fileadmin/uploads/laeo/ Documents/E-book_LEo2011-EN_entier.pdf. Accessed May 6, 2016.

4. Cáceres Rojas E, Gaona MT, Volpe Ríos S, Aguilera J. Educación superior privada en Paraguay. [Higher private education in Paraguay]. Asunción: UCA, IESALC/UNESCO (Programa: Observatorio de la Educación Superior Universitaria Privada en Latinoamérica en el Caribe), 30. 2005. Spanish.

5. Cubilla A. Identificación de problemas académicos en las universidades paraguayas. La universidad en crisis: Seminario Universidad Católica de Asunción y Universidad de Granada - Melilla y otros ensayos. [Identification of academic issues in universities in Paraguay. University in crisis: Catholic University Seminar Assumption and University of Granada - Melilla and other tests]. Asunción: UNESCO/AECI; CIDSEP/UC, 21-62. 2006. Spanish.

6. Perez L. Factores socioeconómicos que inciden en el rezago y la deserción escolar en Deserción, rezago y eficiencia Terminal en las IES. Propuesta metodológica para su estudio. [Socio-economic factors impacting on school drop out, falling behind and educational outcomes at IES. A methodological proposal]. ANUIES. México. 2001. Spanish.

7. Tinto V. El abandono de los estudios superiores: Una Nueva Perspectiva de las Causas del Abandono y su Tratamiento. [Leaving College: Rethinking the Causes and Cures of Student Attrition]. UNAM-ANUIES, México. 1987. Spanish.

8. Tinto V. Leaving College: Rethinking the causes and cures of student attrition. 2nd ed. Chicago: University of Chicago Press; 1993.

9. Tinto V. Research \& practice of student retention: What next? Journal of College Student Retention. 2006;8:1-19.

10. Astin AW. Preventing students from dropping out. San Francisco: Jossey-Bass; 1975.

11. Bean J. Dropouts and turnover: The synthesis and test of a causal model of student attrition. Research in Higher Education. 1980;12(2):155-187.

12. Charnley E. Occupational stress in the newly qualified staff nurse. Nurs Stand. 1999;13(29):33-36.

13. White J, Williams R, Green BF. Discontinuation, leaving reasons, and course evaluation comments of students on the common programme. Nurse Educ Today. 1999;19(2):142-150.

14. Timmins F, Kaliszer M. Absenteeism among nursing students - fact or fiction? J Nurs Manag. 2002;10(5):251-264.

15. Ehrenfeld M, Rotemberg A, Sharon R, Bergman R. Reasons for student attrition on nursing courses: a study. Nurs Stand. 1997;11(23):34-38.

16. Jennings K. Nursing: it is vital to raise the profile of the nursing sector. The Independent. 2002 Mar 26; 2.
17. Glossop C. Student nurse attrition: use of an exit interview procedure to determine students' leaving reasons. Nurse Educ Today. 2002;22(5):375-386.

18. Last L, Fulbrook P. Why do student nurses leave? Suggestions from a Delphi study. Nurse Educ Today. 2003;23(6):449-458.

19. Eiselen R, Geyser H. Factors distinguishing between achievers and at risk students: A qualitative and quantitative synthesis. South African Journal of Higher Education. 2003;17(2):118-130.

20. Troskie-de Bruin C. Academic Development: Bridging at a South African University [D.Ed. thesis]. Stellenbosch: Stellenbosch University; 1999.

21. González LE, Espinoza O. Deserción en Educacion Superior en América Latina y el Caribe. [Drop out in higher education in Latin American and Caribbean countries]. Paideia. 2008;45:33-46. Spanish.

22. Basualdo M. Estudio Sobre la repitencia y deserción en la educación superior en Paraguay. [Study about the grade repetition and drop out from higher education in Paraguay]. Instituto Internacional para la Educación en América Latina y el Caribe. IESALC. 2005. Spanish.

23. Spandonari MM, Luis Alberto Cáceres LC, Siri A. Acceso y permanencia en la Universidad: una investigación en la Universidad Nacional de Caaguazú. [Access and permanence at University: a study carried out at Universidad Nacional de Caaguazú]. X Coloquio Internacional sobre Gestión Universitaria en América del Sur; December 8-10; 2010; Mar del Plata, Argentina. Spanish.

24. Spandonari MM, Luis Alberto Cáceres LC, Siri A. La validez de los exámenes de ingreso en la predicción del éxito académico: un estudio en la Facultad de Ciencias Médicas de la Unc@”. [Validity of entry examinations for predicting academic success and performance: a study carried out at the Faculty of Medical Sciences at Unc@]. Seminario Internacional sobre Gestión Universitaria en América del Sur; September 9; 2011; Coronel Oviedo, Paraguay. Spanish.

25. Siri A. Balancing perception of the job with reality: University and School working together to bridge the gap. A case study in an Italian Medical University. Journal of the World Universities Forum. 2010;3:23-30.

26. Siri A, Rania N, Bagnasco A, Lentini K, Sasso L. From School to University: A Case Study of the Nursing Students. Hellenic Journal of Nursing Science. 2010;3:22-30.

27. Thomas DL, Thomas E, Quinn J. First generation entry into higher education: an international study. London: McGraw-Hill International; 2007.

28. Pascarella ET, Terenzini PT. How College Affects Students: A Third Decade of Research. San Francisco: Jossey-Bass; 2005.

29. Chaffee J. Transforming educational dreams into educational reality. In Zwerling LS, London HB, editors. First-generation students: Confronting the cultural issues, New Directions for Community Colleges. San Francisco: Jossey-Bass; 1992:81-88.

30. Foxcroft C, Stumpf R. What is matric for? Paper presented at: Umalusi Seminar; June 23, 2005; Pretoria, South Africa. Available from: http:// www.umalusi.org.za/docs/assurance/2005/matric.pdf. Accessed May 6, 2016.

31. McKenzie K, Schweitzer R. Who succeeds at university? Factors predicting academic performance in first year Australian university students. Higher Education Research and Development. 2001;20(1): 21-33.
Advances in Medical Education and Practice

\section{Publish your work in this journal}

Advances in Medical Education and Practice is an international, peerreviewed, open access journal that aims to present and publish research on Medical Education covering medical, dental, nursing and allied health care professional education. The journal covers undergraduate education, postgraduate training and continuing medical education Submit your manuscript here: http://www.dovepress.com/advances-in-medical-education-and-practice-journal

\section{Dovepress}

including emerging trends and innovative models linking education, research, and health care services. The manuscript management system is completely online and includes a very quick and fair peer-review system. Visit http://www.dovepress.com/testimonials.php to read real quotes from published authors. 